\title{
THE VALUE OF A SERUM AND ALBUMIN MIXTURE FOR USE IN THE DETECTION OF BLOOD GROUP ANTIGEN-ANTIBODY REACTIONS
}

\author{
BY \\ F. STRATTON AND E. R. DIMOND \\ From the Regional Blood Transfusion Service, Manchester
}

(RECEIVED FOR PUBLICATION JANUARY 25, 1955)

It has been suggested by Wiener and Hurst (1947) and Wiener, Hurst, and Sonn-Gordon (1947) that mixtures of bovine albumin and human plasma are more effective as diluents for the detection of incomplete antibodies than the widely employed $20 \%$ bovine albumin introduced by Diamond and Abelson (1945) or the human plasma alone used by Wiener (1945). This has been confirmed by other workers, and Mollison (1951) has recommended mixing a suspension of red cells in $20 \%$ albumin with the test serum diluted in group AB human plasma.

The present investigation was undertaken to determine whether the $20 \%$ bovine albumin test, which is open to criticism on a number of grounds, could be improved by substituting a mixture of human serum and bovine albumin for the diluent. Human plasma was not used because of clotting difficulties. After initial experiments it was decided to compare $20 \%$ bovine albumin with an equal parts mixture of human serum and $30 \%$ bovine albumin. Saline, and often human serum alone, was also included in the comparisons which were made with respect to different blood group antigen $\rightarrow$ antibody reactions.

\section{Materials and Methods}

Red Cells.-Red cells were obtained in the form of clotted blood. The cells recovered from the clot were washed three times in normal saline and packed. The supernatant saline was completely removed from thes packed cells. They were then resuspended at $10 \%$ strength in the appropriate diluting fluid. The tes? cells were of group $O$ unless otherwise stated.

Human Serum.-The serum used for diluting the bovine albumin was obtained from donors of group $\mathrm{AB}$ and was either fresh or had been kept frozen solid for varying periods of time, and is referred to as $\mathrm{AB}^{2}$ serum. It was free from all blood group antibodie? and had no rouleau-forming properties.

Antisera.-These human sera contained $\mathrm{Rh}$ or other blood group antibodies of various strengths and ha been preserved frozen solid.

Bovine Albumin.-Armour's $30 \%$ bovine albumi (or bovine plasma) was used in the tests. The $20 \%$ albumin was made by diluting this with half it?

TABLE I

RESULTS OF VARIOUS TESTS PERFORMED ON SERA CONTAINING WEAK ANTIBODIES (ANTI-D)

\begin{tabular}{|c|c|c|c|c|c|c|c|c|c|c|c|c|c|c|c|c|c|c|}
\hline \multirow{3}{*}{$\begin{array}{c}\text { Serum } \\
\text { No. }\end{array}$} & \multicolumn{18}{|c|}{ Tests } \\
\hline & \multicolumn{3}{|c|}{ Coombs Test } & \multicolumn{2}{|c|}{$\begin{array}{l}\text { Papainized } \\
\text { Red Cells }\end{array}$} & \multicolumn{3}{|c|}{$\begin{array}{l}\text { Agglutinins } \\
37^{\circ} \mathrm{C} \text {. in } \\
\text { Saline }\end{array}$} & \multicolumn{5}{|c|}{$\begin{array}{l}\text { Titration of Serum in } \\
20 \% \text { Albumin } \\
\text { at } 37^{\circ} \mathbf{C} \text {. }\end{array}$} & \multicolumn{5}{|c|}{$\begin{array}{l}\text { Titration of Serum in } \\
\text { Serum-Albumin Mixture } \times R_{1} r \\
\text { Cells at } 37^{\circ} \mathrm{C} \text {. }\end{array}$} \\
\hline & $\mathbf{R}_{\mathbf{1}} \mathbf{r}$ & $\mathbf{R}_{2} \mathbf{r}$ & $\mathbf{r r}$ & $\left(\mathrm{R}_{1} \mathrm{r}+\mathrm{R}_{2} \mathrm{r}\right)^{*}$ & $\mathbf{r r}$ & $\mathbf{R}_{\mathbf{1}} \mathbf{r}$ & $\mathbf{R}_{\mathbf{2}} \mathbf{r}$ & rr & $1: 1$ & $1: 2$ & $1: 4$ & $1: 8$ & Control & $1: 1$ & $1: 2$ & $1: 4$ & $1: 8$ & Control \\
\hline $\begin{array}{lll}16 & \text { A } & 14 \\
16 & A & 43 \\
20 & F & 15 \\
20 & F & 12\end{array}$ & $\begin{array}{l}++ \\
+ \\
+ \\
+\end{array}$ & $\begin{array}{c}++ \\
+ \\
++ \\
+\end{array}$ & $\begin{array}{l}z \\
z\end{array}$ & $\begin{array}{c}++ \\
++ \\
++ \\
+++\end{array}$ & $\begin{array}{l}- \\
z \\
-\end{array}$ & $\begin{array}{l}\bar{z} \\
=\end{array}$ & $\begin{array}{l}\overline{-} \\
\underline{w} \\
\end{array}$ & $\begin{array}{l}z \\
\overline{-}\end{array}$ & $\begin{array}{l}\bar{z} \\
\bar{w} \\
\mathbf{w}\end{array}$ & $\begin{array}{l}\overline{-} \\
\bar{z}\end{array}$ & $\begin{array}{l}z \\
z \\
z\end{array}$ & $\begin{array}{l}\bar{z} \\
\bar{z}\end{array}$ & $\begin{array}{l}\bar{z} \\
\bar{z}\end{array}$ & $\begin{array}{l}+ \\
+ \\
+ \\
+\end{array}$ & $\frac{\bar{w}}{\overline{+}}$ & $\begin{array}{l}\bar{z} \\
\overline{\mathbf{w}}\end{array}$ & $\begin{array}{l}\overline{-} \\
\overline{-} \\
\end{array}$ & $\begin{array}{l}\overline{-} \\
\bar{z}\end{array}$ \\
\hline $\begin{array}{l}20 \mathrm{G} 15 \\
20 \mathrm{G} 44\end{array}$ & $\begin{array}{c}+++ \\
+++\end{array}$ & $\begin{array}{c}+++ \\
++++\end{array}$ & $\overline{-}$ & $\begin{array}{l}+++ \\
+++\end{array}$ & $\overline{-}$ & - & I & $\overline{-}$ & - & $\overline{-}$ & $\overline{-}$ & $\overline{-}$ & $\overline{-}$ & $\overline{-}$ & $\overline{-}$ & $\overline{-}$ & $\overline{-}$ & $\overline{-}$ \\
\hline
\end{tabular}


volume of saline. The serum-albumin mixtures were made by mixing the necessary volume of serum with $30 \%$ albumin.

Technique.-The tests were performed in tubes 2 in. by $\frac{1}{4}$ in. One volume, $0.05 \mathrm{ml}$., of antiserum was placed in a tube and to this was added one volume of a $10 \%$ suspension of packed cells in the appropriate diluting fluid, i.e., $20 \%$ albumin, serum-albumin mixture, saline, or AB serum. (These tests correspond to the columns headed $1: 1$ in the tables of results.) Titrations were performed by making serial dilutions, viz., $1: 2,1: 4,1: 8$, and so on, of the antiserum in the appropriate fluid and adding one volume of cells suspended in the same fluid to one volume of each dilution. All these tubes were then tapped to mix the contents and incubated normally at $37^{\circ} \mathrm{C}$., in previously warmed racks for two hours. Controls were put up with each titration consisting of one volume of diluent and one of cell suspension in the diluent. Control titrations were also performed using $\mathrm{Rh}$ negative cells in place of $\mathrm{Rh}$-positive ones where the test was concerned with an anti-Rh serum. Similarly, when other typing sera were being tested, positive and negative cells with respect to the particular antigen were used in parallel titrations as test and control. The results were read under the low-power objective of a microscope after gently spreading the sedimented clump from each tube on a slide with a pipette.

Results were scored as follows:

$+++t=$ Massive agglutination with no free cells.

$+++=$ Very strong agglutination with a few free cells.

$+++=$ Many large clumps of cells clearly visible with more free cells.

$++=$ Multiple clumps $(10-12$ cells $)$ just visible to the naked eye, with many free cells.

$+=$ Small clumps (6-8 cells) visible microscopically ; many free cells.

$\mathrm{w}=$ Clumps (3-4 cells) few in number ; many free cells.

$-=$ Negative ; completely free cell suspension.

Anti-globulin or Coombs Test.-As described by Mollison, Mourant, and Race (1952), with modifications suggested by Stratton (1953).
Papainized Red Cells.-These were prepared and used as described by Stratton (1953).

\section{Results}

Preliminary Tests.-A large number of preliminary tests were made to find the best mixture of human serum and $30 \%$ albumin to use as a diluent in the subsequent comparisons with $20 \%$ albumin. The choice of an equal parts by volume mixture was made for the following reasons. It had the advantages of sensitivity and simplicity of preparation. Albumin-rich mixtures were difficult to work with and sedimentation of cells was slow in them owing to viscosity, while mixtures rich in serum lacked sensitivity. A series of experiments relevant to disadvantages in the $20 \%$ albumin test will now be detailed, in which this equal parts mixture of serum and albumin was compared with $20 \%$ albumin. The results are given largely in tabular form and discussed in the final section.

Detection of Weak $R h$ Antibodies.-Table I shows the results of testing sera containing weak anti-D antibodies by various methods. It will be observed that two sera negative in the $20 \%$ albumin test were weakly positive in the serumalbumin diluent, while two others giving very weak reactions in the former diluent gave stronger ones in the latter. All the antibodies in this table were weak but were detected using papainized cells and by the Coombs test. The last two sera in the table contained antibodies not demonstrated in the saline, $20 \%$ albumin or serum-albumin agglutination tests.

Enhancement of Titre of Rh-incomplete Antibodies by the Use of Serum-Albumin Mixture.This enhancement of titre has been described before and was found to be usually two- to eightfold. Fourteen incomplete anti-D sera of various titres were tested and all showed the greater effectiveness of serum-albumin in this respect. The control tests using $\mathrm{Rh}$-negative cells all gave negative results. Table II illustrates a typical case.

TABLE II

SERUM NO. 20 F 3 (INCOMPLETE ANTI-D) TITRATED AGAINST Rh-POSITIVE $\mathbf{R}_{1} \mathbf{R}_{1}$ CELLS IN VARIOUS DILUENTS AT $37^{\circ}$ C.*

\begin{tabular}{|c|c|c|c|c|c|c|c|c|c|c|c|c|}
\hline \multirow{2}{*}{\multicolumn{4}{|c|}{ Diluent }} & \multicolumn{8}{|c|}{ Dilutions } & \multirow{2}{*}{ Control } \\
\hline & & & & $1: 1$ & $1: 2$ & $1: 4$ & $1: 8$ & $1: 16$ & $1: 32$ & $1: 64$ & $1: 128$ & \\
\hline $\begin{array}{l}20 \% \text { albumin } \\
\text { Serum-albumin } \\
\text { Saline } \\
\text { AB serum ... }\end{array}$ & $\begin{array}{l}\cdots \\
\cdots \\
\cdots\end{array}$ & $\begin{array}{l}\cdots \\
\cdots \\
\cdots\end{array}$ & $\begin{array}{l}\cdots \\
\cdots \\
\cdots\end{array}$ & $\begin{array}{c}++++ \\
+++t \\
+\bar{t}+\end{array}$ & $\begin{array}{c}+++ \\
++++ \\
++\end{array}$ & $\begin{array}{c}++ \\
++ \\
\frac{+}{+}\end{array}$ & $\begin{array}{c}+ \\
+ \\
-\end{array}$ & $\begin{array}{c}- \\
++ \\
- \\
-\end{array}$ & $\begin{array}{l}\bar{t} \\
- \\
-\end{array}$ & $\begin{array}{l}\overline{+} \\
- \\
-\end{array}$ & $\begin{array}{l}- \\
- \\
-\end{array}$ & $\begin{array}{l}- \\
- \\
-\end{array}$ \\
\hline
\end{tabular}

* Control titration against $\mathrm{Rh}$-negative cells was negative throughout. 


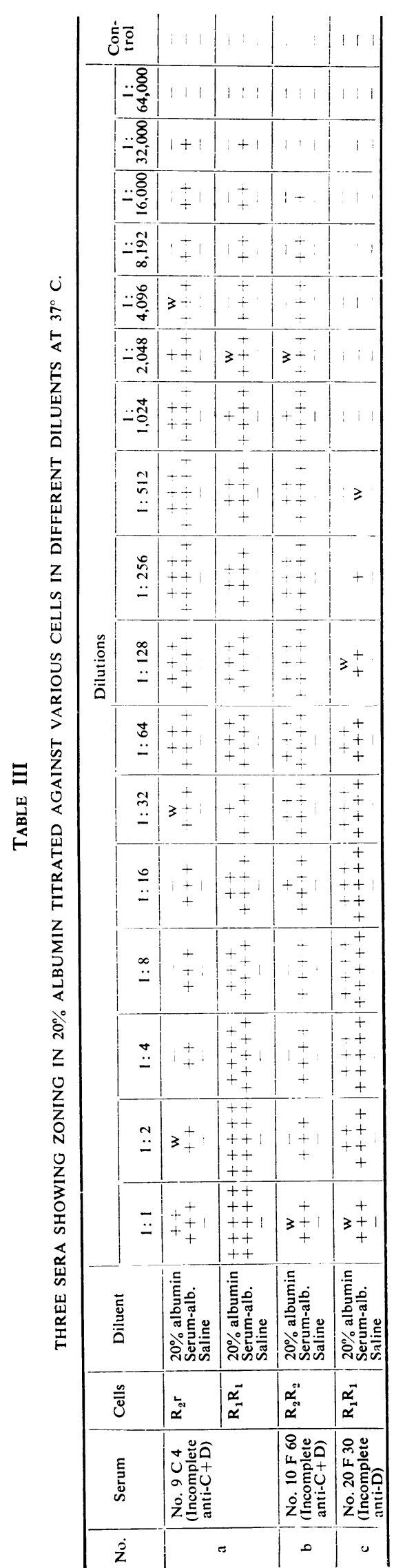

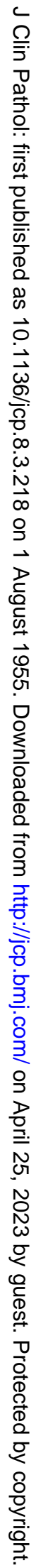


Occurrence of Zoning in Detection of Rh Antibodies.-Table III shows the titration of three anti-Rh sera with various $R h$-positive cells in different diluents. All these sera showed zoning when the titration was performed using $20 \%$ albumin, but the zoning in each case was of a different kind and degree. In Table III (a), the zone using $\mathrm{R}_{2} \mathrm{r}$ test cells was a marked one in the middle of the titration; it did not occur so markedly using type $R_{1} R_{1}(C D e / C D e)$ cells since the serum was of anti-C $+D$ variety and zoning most commonly occurs only with respect to $D$. The serum in Table III (b) showed zoning starting earlier in the titration in $20 \%$ albumin. The third serum (Table III (c)) shows only a slight zone which is most marked in the lower dilutions, $1: 1$, $1: 2$, of the serum. It will be observed that the dilutions which gave negative results within the zones of the $20 \%$ albumin titrations gave unmistakable positive agglutination with serumalbumin. In the case of the second and third sera, if a single tube albumin test were used, the weak result at $1: 1$ might readily have passed unobserved, whereas with serum-albumin the corresponding result was +++ . Serum 20 F 30 (Table III (c)), being anti-D unlike the other two sera, showed a zone in $20 \%$ albumin against both $R_{1}$ and $R_{2}$ type cells.

Detection of Reaction between Incomplete $R h$ Antibodies and $D^{\mathrm{u}}$ Cells.-It is known from previous work (Stratton and Renton, 1949) that $D^{u}$ cells of low grade are not agglutinated by incomplete $\mathrm{Rh}$ antibodies in a $20 \%$ albumin diluent. Table IV (a) shows the titration of an incomplete anti-D serum using various diluents and cells of type $R_{1}^{n} r\left(C D^{u} e / c d e\right)$ low grade. Here the expected negative result was obtained using $20 \%$ albumin, but with serum-albumin the result was positive. It is interesting to note that this titration showed a zone. In Table IV (b) titration of the same serum with ordinary $R_{1} r$ cells $(C D e / c d e)$ using the same diluents is shown. This serum was specially selected and known to be valuable in detecting $D^{u}$ positive cells when using the indirect Coombs technique. When a number of other sera were used, some of lower titre, no agglutination was obtained even using serum-albumin diluent and $C D^{u} /$ cde cells of low grade. Table IV (c) shows the results of titrating the same selected serum with cells of type $R_{2}^{a} r\left(c^{u} E / c d e\right)$ high grade. Here an agglutination was obtained in both $20 \%$ albumin and serum-albumin diluents, but the titre with the latter is much higher and the individual results with each dilution stronger. When a different, incomplete anti-D serum of lower titre was titrated with these high grade $\mathrm{D}^{\mathrm{u}}$ cells, a negative result was obtained using $20 \%$ bovine albumin, but a positive one using serumalbumin diluent (Table IV (d) ).

Detection of Other Varieties of Rh Antibodies. -Other varieties of $\mathrm{Rh}$ antibodies were found to behave in a manner similar to the anti-D and anti-C $+D$ antibodies which have been considered so far. An anti-c antibody (mainly incomplete) had a titre of 1 in 64 in $20 \%$ albumin, 1 in 256 in serum-albumin, and 1 in 4 in saline against $\mathrm{Rh}$ negative (cde/cde) cells, and was completely negative with $R_{1} R_{1}(\mathrm{CDe} / \mathrm{CDe})$ cells in these media. An anti-E antibody of titre 1 in 4 in albumin was of titre 1 in 16 in serum-albumin against $R_{2} R_{2}$ (cDE/cDE) cells and control titrations were again satisfactorily negative using $R_{1} R_{1}$ and $R h$ negative cells.

Detection of Complete Antibodies.-Two varieties of complete antibodies were examined ; first, what was considered to be a serum containing largely complete $\mathrm{Rh}$ antibodies, in view of the fact that its titre was the same in saline, $20 \%$ albumin, and whole serum, namely, 1 in 32 . The titre in serum-albumin mixture was 64 .

Anti-A and anti-B antibodies, some of which had been selected as being of low titre in saline, were titrated out in various diluents against cells of appropriate group. There was no evident enhancement of agglutination using either $20 \%$ albumin or serum-albumin mixture and, indeed, with some sera the results were worse than when a saline diluent was used.

Anti-Kell.-Six anti-Kell sera were titrated with known Kell-positive cells in various diluents ; the results of a typical titration are shown in Table V. It is interesting to observe the negative

TABLE V

TITRATION OF AN ANTI-KELL SERUM (NO. 13 F 1) WITH KELL-POSITIVE CELLS AT $37^{\circ} \mathrm{C}$. IN VARIOUS DILUENTS

\begin{tabular}{|c|c|c|c|c|c|c|c|}
\hline \multirow{2}{*}{ Diluent } & & \multicolumn{5}{|c|}{ Dilutions } & \multirow{2}{*}{ Control } \\
\hline & & $1: 1$ & $1: 2$ & $1: 4$ & $1: 8$ & $1: 16$ & \\
\hline $\begin{array}{l}20 \% \text { albumin } \\
\text { Serum-albumin } \\
\text { Saline } \ldots \\
\text { AB serum }\end{array}$ & $\begin{array}{l}\cdots \\
\cdots \\
\cdots\end{array}$ & $\begin{array}{c}- \\
++ \\
- \\
+++\end{array}$ & $\begin{array}{l}\overline{+} \\
- \\
++\end{array}$ & $\begin{array}{l}\bar{w} \\
- \\
++\end{array}$ & $\begin{array}{l}- \\
\overline{-} \\
+\end{array}$ & $\begin{array}{l}- \\
- \\
-\end{array}$ & $\begin{array}{l}- \\
- \\
-\end{array}$ \\
\hline
\end{tabular}

reaction in the $20 \%$ albumin and the positive result which was obtained in the serum-albumin titration; also an even stronger agglutination occurred in serum alone. Grove-Rasmussen (personal communication) informed us he had found this using several different anti-Kell sera. 
Five out of six anti-Kell sera we examined showed this higher titre in whole serum than in any other diluent.

Anti-Duffy, Anti-S, and Anti-Kidd.-Several examples of each of these sera were tested with the various diluents, but all gave negative results with cells containing the agglutinogen for these antisera.

Anti-Lewis.-Various tests have been made titrating anti-Le $e^{\mathrm{a}}$ and anti-Le ${ }^{\mathrm{b}}$ antibodies with the appropriate cells at $16^{\circ} \mathrm{C}$. and $37^{\circ} \mathrm{C}$., using the usual diluents. The results showed little enhancement of agglutination when $20 \%$ albumin or serum-albumin was used, compared with saline, but it is probably advantageous to use an albumin technique at $37^{\circ} \mathrm{C}$. if it is suspected that incomplete Lewis antibodies are present in a serum.

Effect of Albumin Mixture on Activity of Cold Agglutinins.-Table VI shows the titration of a non-specific cold antibody at $8^{\circ} \mathrm{C}$. and $37^{\circ} \mathrm{C}$. There is little difference between the titres and strengths of agglutination using $20 \%$ albumin and serum-albumin, but both give a higher titre than saline.

\section{TABLE VI}

TITRATION OF SERUM (NO. 12 D 17) CONTAINING A NON-SPECIFIC COLD AGGLUTININ WITH Rh-NEGATIVE CELLS AT $8^{\circ} \mathrm{C}$. AND $37^{\circ} \mathrm{C}$. IN VARIOUS DILUENTS

\begin{tabular}{|c|c|c|c|c|c|c|c|}
\hline \multirow{2}{*}{ Diluent } & \multicolumn{6}{|c|}{ Dilutions } & \multirow{2}{*}{$\begin{array}{l}\text { Con- } \\
\text { trul }\end{array}$} \\
\hline & $1: 1$ & $1: 2$ & $1: 4$ & $1: 8$ & $1: 16$ & $1: 32$ & \\
\hline $\begin{array}{l}\text { (a) } 8^{\circ} \text { C.: } \\
20 \% \text { albumin } \\
\text { Serum-albumin } \\
\text { Saline }\end{array}$ & $\begin{array}{c}++++ \\
++++ \\
+++\end{array}$ & $\begin{array}{c}+++ \\
+++ \\
++\end{array}$ & $\begin{array}{c}+++ \\
++ \\
+\end{array}$ & $\begin{array}{l}++ \\
++ \\
+\end{array}$ & $\begin{array}{l}w \\
\pm \\
-\end{array}$ & $\begin{array}{l}- \\
-\end{array}$ & $\begin{array}{l}\bar{z} \\
-\end{array}$ \\
\hline $\begin{array}{l}\text { (b) } 37^{\circ} \mathrm{C} . \mathrm{:} \\
20 \% \text { albumin } \\
\text { Serum-albumin } \\
\text { Saline } \quad .\end{array}$ & $\begin{array}{l}- \\
-\end{array}$ & $\begin{array}{l}- \\
-\end{array}$ & $\begin{array}{l}- \\
-\end{array}$ & $\begin{array}{l}- \\
-\end{array}$ & $\begin{array}{l}- \\
-\end{array}$ & $\begin{array}{l}- \\
- \\
-\end{array}$ & $\begin{array}{l}- \\
\overline{-}\end{array}$ \\
\hline
\end{tabular}

Centrifugation Experiments.-Experiments were carried out to see whether time could be saved during the performance of albumin tests by centrifuging the tubes following a limited incubation period and then reading the tests. An anti-D serum titrated in both $20 \%$ albumin and serumalbumin mixture was employed. The tubes were incubated for 20 minutes and then centrifuged at low speed (500 r.p.m.) for five minutes and the results read. Comparison with the standard method showed that no serious error would result from using this method if a result is required quickly. Centrifugation experiments have been conducted with only a limited number of anti$\mathrm{Rh}$ sera and not with the full series of tests.

\section{Commentary}

The albumin test, which is widely used for $\stackrel{\overrightarrow{\vec{D}}}{\stackrel{\vec{D}}{+}}$ routine purposes, suffers from certain defects. 으 Some of these can be remedied by using serum- $\overline{\underline{\sigma}}$. albumin mixture in the proportions suggested $\frac{\bar{s}}{\frac{}{\sigma}}$ instead of the $20 \%$ albumin mixture normally $\mathbb{\complement}$ used.

It has been shown (Stratton, 1953) that as many

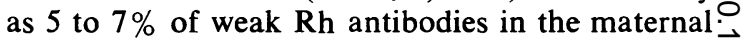
serum might be missed if the $20 \%$ bovine albumin $\vec{\omega}$ test were used alone ; when a serum-albumin mixture is used many fewer $\mathrm{Rh}$ antibodies would remain undetected.

All serological techniques for the detection of ${ }_{i}^{\dot{\omega}}$ blood group antigen-antibody reactions are liable $\vec{\infty}$ to give false negative results due to the occurrenceo of zoning, but the albumin test is particularly prone to this phenomenon. This means that when using $>$ a $20 \%$ bovine albumin diluent a single tube testc cannot safely be employed and the test should be $\frac{2}{\mathscr{C}}$ performed in the form of a titration using up to $\vec{A}$ six tubes. The results reported here show that $O$ a serum-albumin diluent reduces the danger of ${ }^{\mathrm{T}}$ these false negative results. Even where the first? tube of a serum titration shows a weak positive result, due to zoning when $20 \%$ bovine-albumino is used, the substitution of the serum-albumin mixture would result in a stronger positive result. $\stackrel{\mathbb{Q}}{\varrho}$ It should not be assumed, however, that if a serum- $\overrightarrow{0}$ albumin mixture is used every difficulty due to 3 zoning will be eliminated in this test, but false negative results due to this cause will be consider-0. ably diminished.

Stratton and Renton (1949) showed that the Du? type of cells, especially if of low grade, will not react with incomplete anti-D sera in $20 \%$ bovine albumin, but if the $D^{u}$ type of cell is of high? grade occasional positive reactions will be obtained depending upon the incomplete anti-D serum that is used. When a serum-albumin diluent is used, $\rightarrow$ depending upon the particular anti-D sera, some. low grade $D^{u}$ positive cells may be detected; even so, a zone may occur in these titrations. Neverthe less, it would seem that, in a population in which there occurs a large percentage of the $D^{u}$-positivew type of person and where the albumin test is use as a screening test in the first instance for the detection of D-positive persons, materially better: results would be obtained if a serum-albumin ${ }^{\circ}$ mixture were used for the original screening test 0 It should be emphasized that negative results would need to be retested using the Coombs test. One? should not attempt to detect low-grade $D^{u}$ cells using the albumin technique alone, whatever diluent is used. 
Rarely, $\mathrm{Rh}$ antibodies are not detectable by the antiglobulin or other tests, but only using the albumin technique. If these $\mathrm{Rh}$ antibodies are detected in the serum of an $\mathrm{Rh}$-negative mother during the antenatal period, the subsequent sample usually gives a positive indirect Coombs test. Anti-E antibody is one that is most often preferentially detected by the use of the albumin technique.

Kell is an antigen to which persons readily become immunized and anti-Kell antibodies are often detected in human sera. The Coombs test has most often been used for the detection of these antibodies, and the $20 \%$ bovine albumin test does not usually give a positive result. Our results suggest, however, that if serum-albumin is used positive results will be obtained. Grove-Rasmussen (personal communication) suggested that good results were obtained if a serum diluent were used, and this has been confirmed.

Anti-Duffy, anti-Kidd, and sometimes anti-S cannot be detected at all using the albumin technique, whichever diluent is used, and the chances of detecting Lewis antibodies are not materially increased by the substitution of a serum-albumin mixture for a $20 \%$ one.

In the case of anti-A and anti-B saline agglutinins, our impression, after testing many samples, was that these agglutinins are not as readily detected in albumin or in serum-albumin mixtures as they are in saline, although they would be unlikely to give completely negative results in the first two diluents and positive ones in saline.

Experiments were carried out to determine whether the increased rate of sedimentation of the red cells was the sole reason for the enhanced agglutination of the serum-albumin mixture as compared with $20 \%$ albumin. These experiments consisted of reading results of parallel titrations after incubation periods ranging from one to four hours. There was no evidence to support this, since in all cases the serum-albumin results were stronger than those where $20 \%$ albumin was used. These experiments did suggest that economies in time, such as reading the test after one and a half hours' incubation, would not have such serious effects in preventing the detection of positive results if serum-albumin were used as a diluent compared with $20 \%$ bovine albumin. It seems to us, therefore, that the time of incubation might be reduced accordingly when serum-albumin mixture is used. Low-speed centrifugation to reduce the time of incubation was also considered and an incubation time of 20 minutes at $37^{\circ} \mathrm{C}$. in the water-bath followed by low-speed centrifugation (500 r.p.m.) might well be used where speed is desired. Our tests with this technique have only been concerned with a limited number of $R h$ antibodies.

Many observers have shown that other substances will act in the same way as bovine albumin and human plasma or serum. Gelatin and dextran, for example, have been employed, and one of us found, of many substances tried, that methyl cellulose was the best. All these substances suffered from the defect that they tend to cause false positive results which make the interpretation of the test most difficult. The selection of a suitable test medium, therefore, involves finding one which will not give false positive results but will detect blood group antigen-antibody reactions with the minimum of difficulty.

In the authors' experience it is an advantage to add human serum in the proportions suggested to bovine albumin, and such a 50/50 mixture will not increase the false positive results or the difficulty of reading the test. The serum used in making the mixture should be free from blood-group antibodies and all rouleau-forming properties, and we are in favour of freezing it solid at least a week or ten days before making up the mixture. After mixing it is stored at $4^{\circ} \mathrm{C}$. and not kept for more than a few days.

The reading and interpretation of the albumin test have always presented difficulty. The cell deposit should be carefully removed from the tube and spread upon a microscope slide. At this stage aggregation of the red cells is liable to bs present, especially after centrifugation, and gives the effect of comets, i.e., a clump of cells from which a tail of cells can be seen trailing away. It is important to leave the slide. a few minutes on the bench before placing it under the low power of the microscope and then to examine a moving film. This is done by tilting the slide on the stage when the break-up of the cell aggregates will be observed, the true agglutinates remaining intact. In the case of saline agglutination tests, it is often possible to distinguish rouleau from true agglutination microscopically, but in the case of albumin or serumalbumin tests it is quite impossible to make this distinction.

The albumin technique is widely employed in the crossmatching test and often in the form of a single tube test. While the authors would not 
recommend this as a routine method of crossmatching, nevertheless it does seem a considerable advantage to use the serum-albumin mixture suggested in place of $20 \%$ bovine albumin in such a test, and such a mixture would also be advantageous if the test were done in the form of a titration. In the crossmatching test, however, it seems preferable to use a saline agglutination method in tubes at room temperature and at $37^{\circ} \mathrm{C}$. coupled with the use of the antiglobulin technique.
REFERENCES

Diamond, L. K., and Abelson, N. M. (1945). J. Lab. clin. Med., 30, 204 and 668 .

Grove-Rasmussen, M. Personal communication.

Mollison, P. L (1951). Blood Transfusion in Clinical Medicine. Blackwell, Oxford.

Mourant, A. E., and Race, R. R. (1952). The $R h$ Blood Groups and Their Clinical Effects. Medical Research Council Memorandum No. 27. H.M.S.O., London.

Stratton, F. (1953). Lancet, 1, 1169.

— and Renton, P. H. (1949). Brit. med. J., 2, 682.

Wiener, A. S. (1945). J. Lab. clin. Med., 30, 662. and Hurst, J. G. (1947). Exp. Med. Surg., 5, 285.

___ __ and Sonn-Gordon, E. B. (1947). J. exp. Med., 86,' 267. 